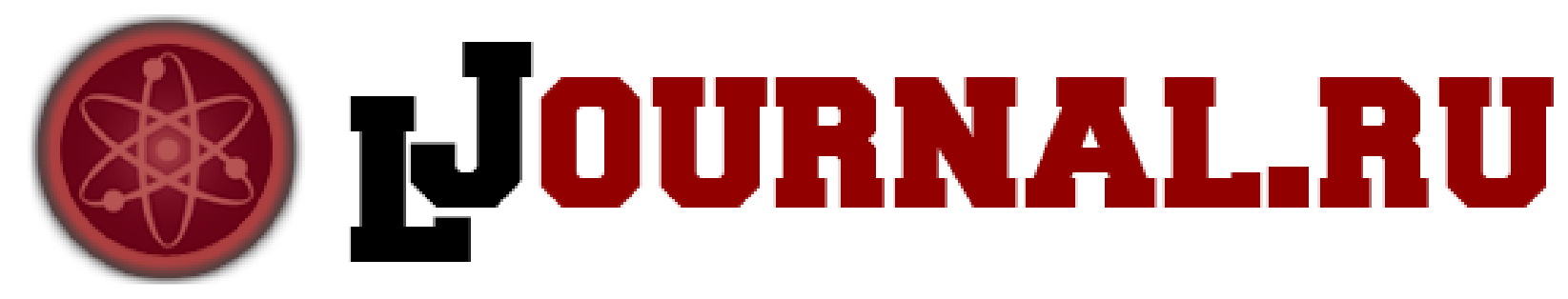

Панфилова О.P. МБОУ СОШ № 8 Россия, Белово

doi: 10.18411/1j2016-2-19

\title{
Традиции русской национальной кухни как учебный концепт на уроках технологии
}

Быт народа складывается под влиянием многих факторов - природноклиматических, исторических, социальных, культурных и т.д. Хотя на него в известной мере влияет социально-культурный обмен с другими народами, но никогда чужие традиции механически не заимствуются, а приобретают на новой почве местный, национальный колорит. Поэтому каждый народ имеет свой уклад жизни, обычаи, свои неповторимые песни, танцы сказки. В каждой стране есть своя кухня, особо любимые блюда, традиции в убранстве стола и приготовлении пищи.

Русская культура прошла многовековую эволюцию. В ней достойное место занимают традиции национальной кухни, которая является отражением образа жизни, привычек, коллективного опыта народа. Кулинарные рецепты, сформированные в результате многовековой эволюции, являются прекрасными образцами правильного сочетания продуктов по вкусу, а с физиологической точки зрения - и по сбалансированному содержанию пищевых веществ. Сегодня, когда через СМИ льется огромный поток предрассудков, необоснованных вредных привычек и лже-советов относительно «правильного питания», особенно важно напомнить о недопустимости легкомысленного пренебрежения к одному из важнейших вопросов человеческого существования. 
Ведь «человек рождается для жизни, а жизнь невозможна без питания» (А.А. Покровский) [3, с. 15]. Не случайно, еще мыслители древности посвящали трактаты лечебным свойствам различных видов пищи и разумному еe употреблению. В правильном питании они видели источник здоровья, силы, бодрости и красоты. В этом ракурсе следует обратить внимание на традиции русской национальной кухни, которая может служить образцом силы и крепости духа, красоты и здоровья.

Следует отметить, что многие особенности русской кухни перешли из славянской культуры. Славянами с давних времен возделывались злаковые (рожь, пшеница, ячмень, просо), выращивались репа, капуста, горох, чечевица и др. Наши предки владели навыками приготовления муки, «тайнами» выпечки различных кулинарных изделий из забродившего теста. Поэтому в пище наших предков существенное значение имели пироги, расстегаи, блины, пирожки, кулебяки, оладьи, блинчики и др. Многие из этих изделий издавна стали традиционными для праздничных столов: курники - на свадьбах, пироги и блины - на масленицу, «жаворонки» из теста - в весенние праздники и т.д. Не менее типичны для русской национальной кухни блюда из всевозможных круп: различные каши, крупеники, овсяные кисели, запеканки и пр.

Блины - одно из самых древних блюд, сопутствующих человеку всю его жизнь - от рождения, когда роженицу кормили блинами, и до смерти, когда на ритуальном поминальном столе так же обязательно должны были быть блины. Блины были всегда любимы как на Руси, так и у многих народов мира. Но только русская кухня знает и умеет готовить сотни самых разных блинов: сдобные и постные, опарные и скородумки, заварные и сливочные, красные, крестьянские, боярские и царские - и, главное, всё это изобилие придумано из одних и тех же продуктов.

Сегодня все знают, что такое блины, но мало кто имеет представление о том, откуда они появились, когда блины стали известны и популярны, в какой стране впервые возникли блины и многое, многое другое. Еще А.П. Чехов 
написал о блинах следующее: «Вы знаете, что блины живут уже более тысячи лет... Они появились на белый свет раньше русской истории, пережили её всю от начала до последней странички, что лежит вне всякого сомнения, выдуманы так же, как и самовар, русскими мозгами... В антропологии они должны занимать такое же почтенное место, как трёхсаженный папоротник или каменный нож; если же у нас до сих пор и нет научных работ относительно блинов, то это объясняется просто тем, что есть блины гораздо легче, чем ломать мозги над ними...» [5]. А.П. Чехов был прав относительно того, что история происхождения блинов покрыта тайной. Поэтому целью работы является: 1) изучение истории возникновения и отражения в русской культуре одного из любимейших национальных блюд - блинов; 2) использование традиций русской национальной кухни в качестве учебного конщепта на уроках технологии.

История возникновения блинов. Единой точки зрения по вопросу о происхождении блинов нет. Одни исследователи считают, что блины были заимствованы в $1 \mathrm{X}$ веке у варягов (вместе с компотами и изварами из сухофруктов). Другие кивают в сторону Китая, хотя китайские блины похожи, скорее, на простые лепёшки, а не на то, что приходит в голову при слове «блин». Некоторые считают, что блины пришли из египетской культуры, хотя ингредиенты и технология изготовления там была совершенно другая. У народов Ближнего Востока было подобное кушанье. Блюдо похожее на блины упоминается и в Библии, и в древних книгах и письменах. И хотя блины в том или ином обличии известны многим народам, классический дрожжевой блин с полным правом может считаться национальным достоянием предков русских людей - славян.

Ещё до принятия христианства, у восточных славян, блины были жертвенным хлебом, а сам Блин считался внуком Даждьбога. Даждьбог - Бог лета, счастья, плодородия, солнечного света, живительной силы и предок русских людей. Историки практически уверены, что ещё в языческие времена блины были непременным атрибутом празднования Весеннего солнцеворота - 
поворотной точки, символизирующей победу дневного света над долгими зимними ночами. В буквальном: смысле - блин это «приготовленный из молотого зерна», то есть «млин». Впервые слово «блин» упоминается в древнерусских писаниях в XIV веке, но ещё как «млин», а в XV - как имя собственное появляется уже «Блин». Нарицательным же блин стал в 1499 году.

По мнению историка В.В. Похлёбкина [4], блины появились на Руси ещё до IX в. Блины - это едва ли не самое экономное мучное блюдо, для которого требуется минимум муки при максимуме жидкости (воды, молока), поскольку для блинов употребляется весьма разжиженное тесто. Ещё более увеличивают объём этого теста дрожжи. Некоторые русские историки считают, что дрожжевые блины появились на Руси в 1005-1006 годах. Встречающееся ныне использование соды для блинов заимствовано с Запада сравнительно недавно и несвойственно русской кухне. Существует много версий возникновения блинов. Вот только одна из них. Однажды, разогревая овсяный кисель, наш предок зазевался, кисель поджарился и подрумянился, так получился первый блин.

Блины в кухнях народов мира. Блины есть в кухнях почти всех народов мира. Везде их готовят разнообразными методами, смешивают самые невероятные ингредиенты. Например, французские, южно-славянские, венгерские, чешские и многие другие европейские блины делаются из теста, полученного из молока, яиц, топлёного масла и муки. В Великобритании блинчики готовят так же, но без добавления масла, поэтому они получаются толстенькими и подаются с разнообразными, чаще всего сладкими, начинками. По размерам в Европе лидируют болгарские палачинки, которые делаются на гигантских сковородах. Интересно, что палачинками блинчики называют и в Венгрии, странах бывшей Югославии, Чехии, Словакии.

Во Франции блины зовутся крепами (crepes). Во французской провинции Бретонь предпочитают блины из гречневой муки - галеты (galette). В отличие от крепов галеты обжаривают только на одной стороне, тогда как вторая покрывается сыром, ветчиной, яйцом и пр. В Голландии блины настолько 
популярны, что там существуют семейные рестораны, специализирующиеся только на голландских блинчиках паннекокен (Pannenkoeken).

В Скандинавии горячие блинчики, приготовленные из картошки, молока и муки, называются лефса (lefse). В Дании в картофельный блинчик трубочкой заворачивают масло, корицу и сахар и подают к кофе как сладкий десерт под названием «тонкая лефса» (tynnlefse). В Норвегии в лефсу (pølse med lompe) охотно заворачивают сосиску - получается «норвежский хот-дог».

Американские и канадские блины существенно отличаются от русских и европейских. Основное отличие - в добавлении пищевой соды и более жирного молока, иногда даже сливок. Американские блинчики (flapjacks) получаются очень пышными, а если в тесто добавляют ещё и корицу, то просто благоухающими. Подаются блинчики, политые кленовым сиропом различных видов.

В Испании, Латинской и Северной Америке, Мексике, Индии и многих других странах мира блинчики чаще всего делают из кукурузной муки и называют тортиллами (Tortilla), от слова torta - круглая лепёшка. В стране басков блинчики называют тало (talo). В Никарагуа они зовутся гуйрила (Güirila) и готовятся исключительно из белой кукурузы, а в Аргентине и Боливии едят сопайпилла (Sopaipilla) - тонкие солёные тортиллы, выпеченные в традиционной печи. В Китае популярны лепёшки лаобин (烙), а в Индии вовсю едят блины роти (Roti).

\section{Блины в русском народном творчестве и произведениях искусства.}

Несмотря на то, что блины в том или ином виде есть в кухнях многих народов мира, но только на Руси существовало самое большое разнообразие блинов, так как без них не обходился ни один праздник и ни одно народное гулянье. Блины всегда были как второй хлеб, поэтому о них складывали сказки и стихи, пели песни. Вот одна из таких русских народных песен под названием «Блины». 


\section{Мы давно блинов не ели, \\ Мы блиночков захотели. \\ Ой, блины, блины, блины, \\ Вы блиночки мои.}

Про блины народ придумал много загадок. Вот некоторые из них: «На плешь капнешь, вставишь, попаришь, вынешь, поправишь» (пекутся блины); «Что на сковородку наливают, да вчетверо сгибают?» (блин); «Поставлю попарю, выну - поправлю, этот сдеру, другой положу» (блин); «Железный ток, свиной перетоп, гречаной посадок» (блины пекут); «Берега круты, река сладка, красные девицы купаются» (блины пекут).

Тема блинов отражена в народных пословицах и поговорках. Приведу две из них с толкованием и примерами употребления. «Первый блин комом» (пословица говорит о том, что первая опыт чаще всего бывает неудачным, т.е. в оправдание за неудачу в начинании). «Тот же блин, да на другом блюде» (применяется в случаях, когда хотят сказать: одно и то же, но в разном виде). А вот еще несколько примеров: «Блин не клин, брюха не расколет»; «Где блины, тут и мы; где оладьи, там и ладно»; «На долго ли собаке горячий блин»; «Блинцы, блинчики, блины, как колеса у Весны»; «Блины и поцелуи счёта не любят»; «Масленица без блинов да именины без пирогов не бывают»; «Масленица идёт, блин да мёд несёт»; «Кому чин, кому блин, а кому и клин».

Довольно часто встречается блин и в русских народных сказках и другой литературе. Например: «На лесной опушке, в тёпленькой избушке, жили-были три братца: воробей крылатый, мышонок мохнатый да блин масленый» [2]. Рассказ А.П. Чехова «Глупый француз» описывает непонятную для иностранцев способность русских поглощать во время еды огромное количество блинов. В «Железной воле» Н. С. Лескова рассказывается о трагикомических приключениях в России немца Гуго Пекторалиса, которые завершаются гибелью героя, подавившегося блином [1].

С блинами у русских людей связаны разные поверья, обычаи, традиции. 
Но прежде всего блины - это обязательное угощение на Масленицу, ставшее как бы необходимым атрибутом весеннего праздника. Об этом напоминают не только многочисленные пословицы, поговорки, припевки (например, «как на масляной неделе в потолок блины летели», «без блина не масляна» и т.д.), но и произведения искусства (стихи, проза, живопись). Русский народ называл масленицу веселою, широкою, разгульною, честною, тридцати братьев сестрою, сорока бабушек внучкою, трех матерей дочкою и т.д. Тот факт, что масленица действительно была разгульным праздником, нашел свое отражение в литературе. Например, в одном из стихотворений, опубликованных в «Сатирическом вестнике» за 1870 год нарисован такой «портрет» русской Масленицы: «Вот вам румяная и жирная богиня, обжорства и питья и драк всех героиня, шатается по городам, по селам, деревням...». А в поэме А.С. Пушкина «Евгений Онегин» есть такие строчки: «Они хранили в жизни мирной привычки милой старины: у них на Масленице жирной водились русские блины». Можно привести примеры из живописи, где сюжетами стали блины и процесс их изготовления (А. Черкашина «Масленица», В. Арбат-Черкасов «Блины с медом», И. Сергеева «Баба Катя», В. Багров «Масленица» и др.).

По традиции праздник Масленицы продолжался неделю, и каждый день имел свое название: понедельник называли встречею, вторник - заигрышем, среду - лакомкой, четверг - переломом или разгулом, пятницу - тещиными вечерями, субботу - золовкиными посиделками, воскресенье - проводами, целовальником, прощеным днем.

На «лакомки», то есть в среду «Масленой недели», тещи приглашали «на блины» зятьев с женами. Особенно этот обычай соблюдался в отношении молодых, недавно поженившихся. Наверняка отсюда и пошло выражение «К теще на блины». Обычно в этот день «для удовольствия любимого зятька» собиралась на гулянье вся местная родня. Зато в пятницу на тещины вечери зять угощал блинами тещу с тестем. Правда, «угощение» было весьма своеобразным. По обычаю, зятья и дочери звали старших поучить их уму-разуму, и такое 
приглашение считалось для родителей великой честью, о нем обычно знали все соседи и родня. Пренебрежение зятя к этой традиции очень тяжело переживалось, осуждалось и поселяло вечную вражду между ним и тещей. Курьез же заключался в том, что званая теща обязана была с вечера прислать в дом к молодым весь блинный скарб: таган, сковороды, черпак и даже кадку, в которой ставится тесто для блинов. Тесть же присылал муку и кадушку с коровьим маслом. Пекли блины, как правило, из дрожжевого теста. Мука бралась самая разная: гречишная, пшеничная, просяная, ячменная и даже гороховая.

Секреты технологии приготовления «русских блинов». Сегодня обычно используют пшеничную муку, а между тем истинно русские блины — из гречишной. Многие современные хозяйки, к сожалению, не имеют даже элементарного представления об этих блинах. Но они стоят того, чтобы вновь занять свое почетное место на нашем столе. Пшеничные блины не имеют той пухлости и рыхлости, какие придает гречневая мука. Кроме того, блины из гречки обладают очень приятным, слегка кисловатым привкусом. Обычно в теплой воде (молоке) разводят дрожжи, а затем, постепенно добавляя в воду (молоко) муку, замешивают тесто. Для опары берут половину всей муки, которая пойдет на блины.

Наиболее рыхлыми и пухлыми они получаются, когда опара замешана на воде. Но на молоке блины вкуснее. Молоко улучшает вязкость и пластичность теста, усиливает процесс его разрыхления, так как наряду со спиртовым брожением, вызванным дрожжами, обеспечивает молочнокислое (кроме свежего молока, для замеса теста можно использовать кефир, пахту, сметану, сливки, сыворотку и другие молочные продукты). Учитывая все это, следует выбрать «золотую середину» и замешивать опару на смеси воды и молока. Замешивать опару следует в деревянной либо эмалированной посуде, размер которой нужно выбрать с учетом того, что объем теста увеличивается в $2-3$ раза. Когда тесто замешано, кастрюлю с ним покрывают полотенцем и ставят в теплое место. Ни в 
коем случае нельзя накрывать посуду с опарой плотной крышкой - тесто должно «дышать». Если опара подходит слишком быстро, ее следует размешать и переставить в более прохладное место. После того, как опара увеличилась в 2 - 3 раза, в кастрюлю добавляют оставшуюся муку и компоненты, которые указаны в рецепте (яичные желтки, соль, сметана, масло и пр.). Тесто тщательно перемешивают и снова ставят в теплое место. После того как тесто поднимется во второй раз, оно готово для выпекания блинов.

На Руси считалось, что блины нужно есть со «смаком», иначе не понять всей прелести этого замечательного блюда (вспомните рассказ А.П. Чехова «О бренности»). Нельзя есть блины наспех, между делом. Они требуют к себе особого отношения и уважения. Лучше готовить их в воскресные или праздничные дни, когда все домочадцы в сборе. Сложнее испечь настоящие блины в будний день при нашей вечной нехватке времени, ведь для этого потребуется не один час. Может быть, стоит возродить старые, добрые традиции и приглашать родственников, друзей специально на блины? Этот день может стать памятным и для гостей, и для хозяев не только из-за вкусных блинов, но и как пример традиционного русского гостеприимства и хлебосольства.

Таким образом, в данной статье была освещена проблема необходимости возрождения традиций русской национальной кухни, как атрибута полноценного правильного питания и здорового образа жизни. Поднятые в статье вопросы, связанные с историей блинов, секретами их приготовления и употребления через раскрытие особенностей русской кухни и национальной культуры способствуют правильному питанию и укреплению здоровья. В заключение приведу слова И. П. Павлова: «Человек - высший продукт земной природы. Человек - сложнейшая и тончайшая система. Но для того, чтобы использовать сокровища природы, чтобы этими сокровищами наслаждаться, человек должен быть здоровылм, сильнымм и умнылм...». 


\section{Литература:}

1. Лесков Н.С. Повести. Рассказы. - М.: Художественная литература, 1973.$560 \mathrm{c}$.

2. Крылатый, мохнатый да масленый. Русская народна сказка [электронный pecypc]: htpp:// kirskas.ru, hyaenidae.narod.ru>

3. Покровский А.А. Беседы о питании. - М.: Экономика, 1986. - 367 с.

4. Похлебкин В.В. Большая энциклопедия кулинарного искусства. Все рецепты B.В. Похлебкина. - М., 2008 [электронный ресурс]: htpp:// PLAM.RU

5. Чехов А.П. Блины [электронный ресурс]: htpp:// articles/anton-chehovpancake.html 